\title{
FEDERALISMO, LIBERDADE E DIREITOS FUNDAMENTAIS
}

\author{
MisABEl AbReU MACHADO DeRZI ${ }^{\dagger}$
}

\section{INTRODUÇÃO}

O Só quem não soube a sombra, não reconhece a luz, diz o Ministro Barroso, de nossa Corte Suprema, em seu livro, O novo Direito Constitucional Brasileiro, referindo-se à Constituição de 1988, como "rito de passagem para a democracia, para a maturidade institucional" nacional, após período de ditadura militar vivenciado pelo País. Em suas palavras: "a Constituição de 1988 é o símbolo maior de uma história de sucesso: a transição de um Estado autoritário, intolerante e muitas vezes violento, para um Estado Democrático de Direito."1

Neste texto, dentro do mesmo espírito de transição para a liberdade, que a nossa Constituição vigente introduziu, vamos abordar o Federalismo. O Federalismo recuperado, restabelecido, após os abalos desencadeados no período ditatorial anterior. Enfim, um Federalismo que, na Constituição, sofre remodelação, revigoramento, quer do ponto de vista político, quer do ponto de vista financeiro. Um Federalismo apto a garantir a liberdade, como sempre foi sua função. Só quem não soube a sombra, não reconhece a luz.

\section{Combatendo a força de três preconceitos}

Argumentos antifederativos, que prejudicam a compreensão da regra e dos princípios que inspiram o Federalismo, usualmente, são preconceitos que não se sustentam.

O primeiro é, há muitos anos, referido e repetido. A ideia de que a corrupção no Brasil seria maior no âmbito municipal e estadual. Ela seria, praticamente, inexistente na esfera federal, pretensamente dotada de técnicas mais eficientes de controle. A decepcionante realidade, desvelada recentemente, com denúncias e acusações de corrupção envolvendo a cúpula do governo federal, demonstra-nos que tais fatos não são verdadeiros. Integridade, honestidade não derivam do fato de se

\footnotetext{
+ Professora Titular de Dir. Tributário e Financeiro da UFMG e das Faculdades Milton Campos. Doutora em Dir. Público pela UFMG. Pres. Honorária da ABRADT e Pres. da Comissão Permanente de Revisão e Simplificação da Legislação Tributária do Estado de Minas Gerais

${ }^{1}$ Cf. BARROSO, Luís Roberto. BARROSO, Luís Roberto. O novo direito constitucional brasileiro: contribuições para construção teórica e prática da jurisdição constitucional no Brasil. Editora Fórum, 2012, p.26.
} 
estar na administração municipal, estadual ou federal. É questão de caráter.

O segundo preconceito alcança a ideia de que os Estados seriam "caloteiros", ou seja, não estariam a honrar os seus deveres de pagar religiosamente as suas dívidas, dívidas que têm com a União. O olhar de muitos para o sofrido Estado do Rio de Janeiro não seria de complacência, nem de misericórdia ou solidariedade mas de crítica a seus administradores incompetentes e governadores, aliás acusados de corrupção. As negociações são duras e a postura da União é a de quem lida com caloteiros contumazes. Não obstante, a União também deve aos Estados quantias bilionárias, não cumpre seus deveres de compensação em razão da desoneração advinda da Lei Complementar 87/96 (Kandir), fato reconhecido, por unanimidade, pelo Supremo Tribunal Federal, além de praticar uma série de manobras e manipulações inconstitucionais, decepando a receita dos Estados, até mesmo do imposto sobre heranças e doações, como veremos em seguida.

Finalmente, supõem alguns que a União congrega a gente mais preparada e o aparato administrativo mais adequado, sendo a gestão federal melhor, muito melhor do que a estadual ou a municipal. Não podemos ver dessa forma. A realidade é outra. A União não cumpre suas metas fiscais obrigatórias e vive alterando-as, embora tenha disponibilidade para perdoar dívidas bilionárias no setor do agronegócio, além de irrigar as bases políticas de deputados com recursos públicos, visando a interesses pessoais do governante. A União, além do mais, tem muitos recursos ou técnicas de que se pode socorrer (mas não os Estados) para honrar os serviços públicos de sua competência. Dá-se, no âmbito doméstico, simples replicação do argumento da maior expertise com que, no plano internacional, os países desenvolvidos também impõem normas e procedimentos, inclusive na área tributária, aos países em desenvolvimento. ${ }^{2}$

\footnotetext{
2 São várias as menções, quer do ponto de vista econômico, quer do ponto de vista filosófico, ao fenômeno da utilização da pretensa especialização e expertise, como técnicas de dominação. Entre outros, ver STIGLITZ, Joseph E. The Euro: how a common currency threatens the future of Europe. Nova York. Northon y Company, 2016; SOUZA, Jessé. A tolice da Inteligência Humana: ou como o País se deixa manipular pela elite. São Paulo. Leya, 2015; FOUCAULT, Michel. A verdade e as Formas Jurídicas. Trad. Roberto Cabral de M. Machado e outro. 4a. Rio de Janeiro. Cadernos da PUC/RJ n. 16, 1979; FISCHER, Frank. Democracy and Expertise: reorienting public inquiry. Oxford University Press. 2009.
} 
Enfim esses três preconceitos devem ser eliminados para conseguirmos analisar e pensar o Federalismo e os desvios que se the fazem na hora presente.

\section{O conceito de estado federativo somente é deduzido da análise sistemática e globalizada de cada ordem jurídica}

Ora, nenhum dispositivo da Constituição pode ser interpretado isoladamente. Em regra, os tribunais constitucionais não fazem uma opção clara por uma técnica ou método de interpretação. Assim acontece no Tribunal Constitucional norte-americano, no alemão e no brasileiro. Mas nenhum juízo, instância ou tribunal admite a interpretação meramente literal, tópica e assistemática, ofensiva de outros valores e normas constitucionais. Na Alemanha, o Tribunal não adota nenhum método de interpretação determinado, ao contrário, costuma fundamentar suas decisões se socorrendo da combinação de técnicas diferentes e pontos de vista distintos. ${ }^{3}$

A Suprema Corte dos EEUU igualmente não se fixou em nenhum modo de análise, técnica ou método isoladamente. Ora adota o estruturalismo sistemático, buscando a unidade de sentido, por meio de princípios fundamentais, ora o método analítico do razoável, partindo da premissa de que a Constituição não é um "pacto suicida". ${ }^{4}$

\footnotetext{
${ }^{3}$ Entretanto, apesar disso, o BVerfG já reconheceu expressamente as seguintes regras de interpretação e aplicação da Constituição, como observam RICHTER, Ingo; SCHUPPERT, Gunnar Folke. Casebook Verfassungsrecht. CH Beck, 1987, p. 9: “...Atrás da fórmula do "querer objetivado do legislador", impõe-se a chamada teoria objetiva, que é a vontade do legislador expressa na Constituição, não prevalecendo a "vontade real"; o BVerfG recusa expressamente a teoria subjetiva. Segundo o Tribunal, "A interpretação da "vontade objetivada" dirige-se segundo:a) a palavra (interpretação literal ou gramatical);b) o contexto no qual a norma se insere (na Constituição ou no Direito, ou seja, pela interpretação sistemática); c) o fim (interpretação teleológica), sendo que esses três pontos se completam uns aos outros."; finalmente, ver ainda MAGALHÃES, Tarcísio Diniz. Governança Tributária Global: limitações externas ao poder de tributar e de não tributar na pós-modernidade. Belo Horizonte: Arraes, 2016.

${ }^{4}$ Às vezes se prende à conservadora interpretação autêntica, literal, mas busca, ainda, às vezes se utilizar da interpretação teleológica seja para reforçar a democracia no sentido de separação de poderes, a fim de retrair a criatividade do Poder Judiciário (como o fez o juiz FÉLIX FRANKFURTER, ao invocar a presunção de constitucionalidade em favor do legislador) seja para reforçar a democracia representativa dos processos políticos abertos (como o consentiu o juiz HARLAN
} 


\section{FEDERALISMO, LIBERDADE E DIREITOS FUNDAMENTAIS}

Também o nosso Supremo Tribunal Federal trata de dar efetividade aos preceitos da Carta, através de criatividade estruturadora e sistemática, por meio de um certo balanceamento controlado de valores e de interesses, que na Carta se complementam. Hoje, o constitucionalismo vê a Constituição como um sistema de normas que aspira a uma unidade de sentido e de compreensão, unidade essa que somente pode ser dada por meio de princípios, continuamente revistos, recompreendidos e reexpressos pelos intérpretes e aplicadores do Texto Magno. Portanto, a própria noção de interpretação é sempre norteada pela vontade objetivada do Constituinte e compreendida dentro de um sistema normativo em que os princípios e os fins norteiam o sentido.

É difícil, pois, extrair de certa ordem jurídica o modelo federativo, quer do ponto de vista formal, quer material, pois pressupõe-se o conhecimento sistematizado do ordenamento, seus pesos e contrapesos.

\section{Fundamentos e fins inerentes ao federalismo}

A meta neste artigo não é inovarmos na teoria do Federalismo, nem tampouco resumirmos as diversas correntes, conceitos e conceituações que a Ciência do Estado e do Direito, ao longo dos séculos, já delinearam. Uma biblioteca inteira pode ser considerada para a explicação e a compreensão dessa forma de Estado. ${ }^{5}$ Nosso objetivo é singelamente

STONE, no caso dos produtos Carolene, de 1938). O juiz STONE recomendou que se deve desconsiderar a presunção de constitucionalidade naqueles casos em que " $a$ legislação restringe o processo político... e deve ser submetida a julgamento judicial mais rigoroso... do que a maioria dos outros tipos de legislação". Cf. MURPHY, Walter F. et al. American Constitucional Interpretation. Mineola. New York: The Foundation Press Inc. 1986, p. 298.

${ }^{5}$ No Brasil, para citarmos apenas os clássicos, é imprescindível lembrar BARBOSA, RUI. Obras Completas, vol. VUU, t.1.; A Constituição de 1891. Rio de Janeiro, 1946, p. 313; HORTA, Raul Machado. Estudos de Direito Constitucional, Belo Horizonte: Del Rey, 1995; MIRANDA, Pontes de. Comentários à Constituição de 1967. São Paulo: Revista dos Tribunais, v. 4, 1967; BALEEIRO, Aliomar. Limitações Constitucionais ao Poder de Tributar. Atualiz. DERZI, Misabel. 8ª ed. Rio de Janeiro, 2010; SILVA, José Afonso da. Curso de Direito Constitucional Positivo. 9 ed. São Paulo: Malheiros, 1994; AGUIAR, Joaquim de Castro de. Competência e Autonomia dos Municípios na nova Constituição. Rio de Janeiro: Forense, 1993; FERRARI, Sérgio. Constituição Estadual e Federação. Rio de Janeiro: Lumen Iuris, 2003; BARROSO, Luís Roberto. Direito Constitucional Brasileiro: o problema da Federação. Rio de Janeiro: Forense, 1982; BARACHO, José A. O., Teoria Geral do Federalismo. UCMG, 1982. 
relembrar os fundamentos mais relevantes e os fins do Federalismo para respondermos à indagação: por que razão podemos e devemos comparar o Federalismo alemão com o Federalismo brasileiro?

O Brasil, desde sua independência, sempre foi gerido de forma centralizada, ${ }^{6}$ embora nossa primeira Constituição republicana tivesse escolhido a forma federativa de Estado. Entretanto, após longo período de ditadura militar (1964-1985), a Constituição da República Federativa do Brasil de 1988 (CRFB/1988) buscou formatar uma verdadeira Federação que pudesse romper com essa tradição. No intuito de redemocratizar o País, a CRFB/88 firmou o federalismo ${ }^{7}$ como princípio constitucional garantidor da descentralização do poder político e financeiro. $\mathrm{O}$ princípio federativo aparece como cláusula intangível, razão pela qual a manutenção do equilíbrio federativo firma-se como norma a ser mantida incólume, não se admitindo sua ruptura sequer por emendas constitucionais. Trata-se, enfim, de mandamento basilar que deve garantir o intento democrático-descentralizador da CRFB/88. Nela, o Federalismo não apenas foi erigido como cláusula intangível, mas novo desenho das competências tributárias e financeiras procurou dotar Estados membros e Municípios de recursos suficientes com que suportar suficientemente o custo dos serviços públicos atribuídos.

Foi assim que a nova Constituição descentralizou o poder. Em um país, como o nosso, de dimensões continentais e de democracia intermitente, não se deveria mais admitir que o Brasil fosse comandado

\footnotetext{
${ }^{6}$ Se a coroa brasileira buscou manter a unidade do país centralizando o poder nas mãos do imperador, o governo militar deixava em Brasília todas as decisões da República. A propósito, vale consultar BATISTA JÚNIOR, Onofre Alves. O projeto democráticodescentralizador da Constituição e o acerto de contas. Revista Consultor Jurídico. Disponível em: <http://www.conjur.com.br/2017-jun-27/onofre-junior-projetodemocratico-descentralizador-constituicao $>$. Acesso em: 28 jun. 2017.

7 Nesse sentido, DERZI, Misabel Abreu Machado; BUSTAMANTE, Thomas da Rosa de. Federalismo, justiça distributiva e royalties do petróleo: três escritos sobre Direito Constitucional e o Estado federal brasileiro. Belo Horizonte: Arraes, 2016, p. 08, quando expõem que não se deve pensar no Federalismo apenas como forma de Estado, mas antes como princípio de organização política, uma vez que está vinculado diretamente a um emaranhado de valores políticos e princípios constitucionais dotados de conteúdo normativo mais específico, relacionados às ideias de autonomia política e autodeterminação do indivíduo. Ver DERZI et al. O Princípio Federativo e a Igualdade: Uma Perspectiva crítica para o Sistema Jurídico Brasileiro a partir da Análise do Modelo alemão. In: Federalismo e Tributação. Belo Horizonte: Arraes Ed., 2015, p. 467-495.
} 
por um grupo centralizado em Brasília, mas deveria ser uma Federação, com pessoas políticas autônomas (soberanas como dizem os norteamericanos). Nunca é demais frisar que a CRFB/88 surgiu em um contexto de redemocratização em que o princípio federal, desde sua origem, resultou menos da pressão da realidade como fato sociológico anteposto, e mais de uma decisão político-jurídica, para cumprir uma função adicional que não pode ser negligenciada: a de preservação da democracia e da liberdade. Essa a meta principal: preservação da democracia e da liberdade.

Trajetória similar foi feita pela Alemanha após a segunda grande guerra. Embora já tivesse dado origem a uma Confederação de Estados independentes (de 1815 a 1866), o Estado alemão esteve unificado por mais de dez anos, durante a ditadura do nacional socialismo de 1934 a 1945. Por isso, explicam ${ }^{8}$ RICHTER E SCHUPPERT, deu-se uma decisão, em favor do Estado federativo, no ano de 1949, por vários motivos:

a) o surgimento da República federativa da Alemanha ocidental que encontra os já existentes Estados federativos;

b) a manutenção em aberto da República federativa para o ingresso de outros Estados;

c) a insistência das forças de ocupação ocidentais, na adoção do princípio federal;

d) o desejo de evitar o retorno de uma ditadura do III Reich, que caracterizou a consciência dos novos democratas.

Dizem os constitucionalistas alemães que não basta hoje garantir a separação entre os poderes (um poder enfrentando e equilibrando o outro: só o poder contém o poder) que é uma divisão horizontal do poder. Para países que já experimentaram regimes totalitários, ainda é necessário diluir o poder do ponto de vista territorial.

Só quem não soube a sombra, não reconhece a luz.

Embora não tenhamos tido fortes raízes históricas ligadas ao Federalismo, a intermitência da democracia brasileira recomendou e ainda recomenda a adoção dessa forma de Estado e sua manutenção. E não importam as críticas que possam ser levantadas e nem os custos. Vale a pena. O papel que cumpre o Estado federal, como garantia adicional da liberdade e da República democrática, é suficiente para legitimá-lo.

Daí que a comparação entre o nosso Federalismo e o norte-americano seria frustrante.

Primeiramente os EEUU nasceram sob o signo do Federalismo e dos direitos fundamentais, individuais. Essa sua origem e marca. Parodiando James Madison (em o Federalista) podemos dizer que a república

${ }^{8}$ Cf. Casebook Verfassungsrecht, München, Verlag C. H. Beck, 1987, p. 358. 
americana está assentada em um poder dividido entre distintos governos e então dá-se uma dupla segurança em relação aos direitos individuais do cidadão. Os diferentes governos controlam um ao outro (naquele modo de que somente o poder limita o poder) e, ao mesmo tempo, cada um deles será controlado em si mesmo. E os cidadãos, na defesa de seus direitos civis, podem se voltar contra ambos. Na visão de Madison, o federalismo tem a virtude de dividir o poder para preservar a liberdade. ${ }^{9}$

Em um trabalho muito interessante, Michael Dorf ${ }^{10}$, faz um levantamento do pensamento dos juízes da Corte Suprema norteamericana para identificar as inclinações mais ou menos federalistas de cada um deles, ao longo dos tempos. Além da clássica visão de Madison, invocada pelo juiz Kennedy, no caso United States v. Lopes, O'Connor, em outro caso, Gregory v. Ashcroft (1991), adicionam-se várias outras vantagens ou virtudes do Federalismo. Enfim, diz o autor da pesquisa, Dorf, ao longo dos anos, em diferentes casos, a Corte Suprema norteamericana elaborou a seguinte lista de virtudes do federalismo: 1. a divisão do poder; 2. a descentralização/especialização para atender às peculiaridades locais; entre nós falaríamos ainda de subsidiariedade... 3. a responsabilidade democrática, por força da qual o governo federal não pode impor aos estados a aprovação de certa lei... isso seria privar os eleitores de seu poder decisório e de cobrar e exercer a democracia por meio de seus representantes; 4 . a experimentação, princípio que autoriza as inovações estaduais sem comprometer o resto do país; 5 . competição como estímulo ao governo federal e aos estados.

Enfim, é difícil estabelecer comparação entre o nosso Federalismo com aquele da República do Norte em que se chega ou se chegou a discutir se a soberania federal advém do povo norte-americano como um todo ou se vem da soberania dos estados, ou seja, dos cidadãos de todos os Estados individualmente considerados. Enfim não faremos isso. Basta lembrar resumidamente que lá a competência legislativa e política dos Estados é larga e intensa. Além disso, lá a Constituição dá aos Estados importantes poderes de ação nacional. AÇÃO DE POLÍTICA CONJUNTA. São tais poderes, um Senado que os representa, de forma paritária; a real participação dos Estados no Colégio Eleitoral, nas complexas eleições presidenciais, e, finalmente, a necessidade de ratificação por cada Estado de cada emenda constitucional. Enfim, dá-se uma real

${ }^{9}$ Cf. HAMILTON, Alexander; MADISON, James. JAY, John. MADISON, James. O Federalista, XLVII. Rio de Janeiro: Nacional de Direito, 1959.

${ }^{10} \mathrm{Cf}$. DORF, Michael C. Instrumental and Non-Instrumental Federalism. Rutgers LJ, v. 28, 1996, p. 825 . 
soberania/autonomia dos Estados em face da União. Além disso, não podemos denominar a democracia norte-americana de intermitente, embora a consciência de que o Federalismo serve à liberdade e aos direitos e garantias constitucionais pareça forte naquela república do Norte. ${ }^{11}$

Esse não é o caso do Brasil, nem se pode dizer que foi o caso da Alemanha. Na Alemanha não se esconde: há necessidade de se dividir o poder para se preservar a liberdade. Além disso, o Federalismo alemão e o brasileiro estão fortemente impactados pela igualdade.

Não se nega a possibilidade de a forma unitária de Estado conviver com regimes políticos que adotam o princípio democrático, nem tampouco o princípio federal representa defesa absoluta contra os regimes ditatoriais. Mas a descentralização de poder, peculiar à forma federal de Estado, acarreta mais facilmente a república democrática, dificultando o totalitarismo. Afinal, enriquecer o Federalismo, dotando de maior autonomia os entes estatais que o compõem, ampliar a competência legislativa de Estados-membros e Municípios, é dar maior espaço à Co deliberação e à autodeterminação popular. Quem quer concentrar não dilui o poder pelo território nacional, diluição que é característica do Federalismo.

Como alerta Michael Bothe ${ }^{12}$, embora o federalismo seja um conceito em constante transformação histórica, pode-se dizer que a decisão por um Estado federal é uma decisão pela liberdade e não deixa de ser uma decisão pela igualdade, na medida em que se respeitam as diferenças e peculiaridades locais e regionais.

Sim, por duas razões relevantes podemos e devemos comparar o Federalismo brasileiro ao alemão. Em primeiro lugar porque vivemos experiências de democracia intermitente tal como já ocorreu na Alemanha, país que, não obstante teve sucesso na implantação de um Federalismo de Política conjunta. Acresce ainda que tanto a Constituição alemã consagra o Estado Social e modela um Federalismo fortemente impactado pela igualdade quanto a Constituição brasileira, de 1988, está imantada pelo Estado Democrático de Direito e pelas metas de erradicação da miséria e redução das grandes desigualdades econômicas. São complexas as causas em razão das quais temos menor sucesso do que os tedescos. Nossas circunstâncias são um problema que não haverá de

${ }^{11}$ Cf. DORF, Michael. Instrumental and Non-Instrumental Federalism. Rutgers LJ, v. 28, 1996, p. 825.

12 BOTHE, Michael. Federalismo, um conceito em transformação histórica. In: SCHULTZE, Rainer-Olaf O. Federalismo na Alemanha. Fundação Konrad AdenauerStiftung: Traduções, n. 7, 1995, p. 03-14. 
ser examinado aqui. $\mathrm{O}$ objetivo é destacar, chamar a atenção para o fato de que não somos ainda um Federalismo de política conjunta, nem voltado firmemente à equalização entre grupos, regiões e cidadãos individualmente considerados.

\section{O PRINCÍPIO FEDERATIVO DO PONTO DE VISTA FORMAL E MATERIAL}

Alguns constitucionalistas, nacionais e estrangeiros, referem o fato de que é difícil, senão impossível definir estado federal. A observação é verdadeira, na medida em que as variações quantitativas são quase infinitas e, em termos ideais, não se pode dizer qual modelo seria correto para o Estado A ou B. Entretanto, a variabilidade de um instituto não significa que qualquer coisa possa ser aceita, nem tampouco que inexistam parâmetros mínimos ou lindes, além dos quais compromete-se a existência do Federalismo. A questão cresce de importância na ordem jurídica nacional em que a Constituição proíbe se delibere sobre "proposta de emenda tendente a abolir a forma federativa de Estado"(art. 60, §4").

Parece certo, pois, que Federalismo é uma questão de grau e que cada país, em um campo de tensão entre forças centrífugas, desintegradoras e de diversidade que se opõem a forças centrípetas, integradoras e unificadoras, encontra pontos distintos de equilíbrio. Trata-se de um conceito em transformação histórica (e não serão todos eles?), em que se conhecem diversificações entre dois extremos: a forte interdependência política, inerente ao modelo alemão, e o modelo predominantemente dual do regime norte-americano. ${ }^{13}$

\section{O federalismo formal}

Se fizermos abstração dos fundamentos e metas a que se presta o Federalismo e mais ainda, da matéria, sua extensão e quantidade, alcançaremos aquilo que denominamos, singelamente, de federalismo meramente formal.

Ora, um Estado-membro não goza apenas de autonomia administrativa e financeira, nem apenas de personalidade pública. Tratase de ente político, a que é atribuída parcela de poder estatal, de tal modo que a ordem jurídica que somente vale em seu âmbito territorial nasce de

${ }^{13}$ Cf. BOTHE, Michael. Federalismo, um conceito em transformação histórica. In: SCHULTZE, Rainer-Olaf O. Federalismo na Alemanha. Fundação Konrad AdenauerStiftung: Traduções, n. 7, 1995, p. 03-14. 
fonte legislativa própria. O Estado-membro, como Estado Federado, se auto ordena uma ordem jurídica própria. E pessoa inconfundível com autarquia, ente dotado de certa independência administrativa e gerencial, jamais um ser político-estatal. Como ser estatal, o Estado-membro nasce originalmente na Constituição Federal, no mesmo instante, forma e com as limitações ali impostas. Não é criatura da União, mas com ela nasce junto, integrando vínculo indissolúvel no concerto federativo. A essência do Federalismo não está apenas na relativa descentralização administrativa ou financeira, fenômeno comum ao Estado unitário, mas ainda na relativa autonomia político-jurídica dos Estados que o integram. Quer se forme por meio da livre unificação de totalidades políticas diferenciadas (aproximação por força centrípeta), quer por meio da divisão de um corpo político único em entes diversos (certa dispersão por força centrífuga), todo Estado Federal repousa na absoluta igualdade de direitos entre os Estados e nos deveres recíprocos da União e dos Estados de lealdade, ajuda e solidariedade. A descentralização político-jurídica que o caracteriza pressupõe descentralização do poder e se reconhece

quando a ordem jurídica, válida somente para uma comunidade parcial, é criada por órgãos eleitos simplesmente pelos membros dessa comunidade parcial. Como exemplo poderia citar-se um Estado federal em que as leis válidas para o território de um Estado-membro unicamente podem ser expedidas pelo legislativo local, eleito pelos cidadãos desse Estadomembro. ${ }^{14}$

De fato, estabelece o caput do art. 18 da Constituição Federal:

A organização político-administrativa da República Federativa do Brasil compreende a União, os Estados, o Distrito Federal e os Municípios, todos autônomos, nos termos desta Constituição.

Assim, no Federalismo, formalmente estudado, à luz da competência privativa do Estado-membro, ou concorrente, encontramos um conjunto de normas - que compõem a ordem jurídica parcial - e que somente nascem, têm vigência e eficácia, se postas pelo Poder Legislativo estadual,

${ }^{14}$ Cf. KELSEN, Hans. Teoria General del Derecho y del Estado. Trad. Eduardo Garcia Maynez. 2a. ed. México: Imprenta Universitária, 1958, p. 268. 
sendo irrelevantes e impotentes quaisquer outros atos normativos da União. A jurisprudência do STF nessa questão é farta. Firmou-se entre nós o entendimento de que a Constituição atribui competência, distribuindo o poder de tributar entre os entes políticos da Federação. As normas gerais, editadas em leis complementares federais, somente encerram as chamadas normas-quadro, ou normas sobre como devem ser elaboradas outras normas, quadro dentro do qual se há de exercer a competência da União, dos Estados e do Distrito Federal. Mas somente a lei da pessoa competente (que deve estar em consonância com a Constituição e as normas gerais) pode colocar em vigor aquela matéria, inerente à ordem jurídica parcial. A presença mais intensa ou não de normas de repetição (das normas gerais federais cogentes), no âmbito estadual ou municipal, é questão inerente ao Federalismo no sentido material. Formalmente, sem $\mathrm{o}$ ato de vontade do legislador local ou regional, não surgem normas válidas de Direito Tributário, Administrativo ou Financeiro, etc., naquelas ordens jurídicas parciais. Tão somente em relação à matéria de competência legislativa exclusiva da União, por ela monopolizada, evidentemente é que tal questão não se põe. É o que sucede no Direito Civil, Penal, etc.

Feita abstração do conteúdo material das normas editadas pelos Estados e pelos Municípios, sua extensão, quantidade e a intensidade das normas de repetição, constatamos que, em todo estado federal, além da ordem jurídica total, ordens jurídicas parciais convivem entre si, ordens essas necessitadas que nascem de poder legislativo próprio, específico, único apto a produzir normas válidas naquela esfera estatal. Nesse sentido, jurídico formal, as ordens jurídicas parciais são absolutamente iguais, nenhuma delas podendo interferir na outra. Impõem-se, então, a igualdade jurídico-formal entre as ordens envolvidas e os deveres de solidariedade e lealdade, inerentes à forma federativa.

Não são, entretanto, mesmo nesse ponto, estritamente formal, idênticas as soluções encontradas em cada modelo de Estado federal. Nos Estados Unidos da América, p.ex., é lenta a alteração das normas constitucionais, pois as emendas praticamente devem ser "recepcionadas" por cada um dos Estados Federados. Nesse ponto, manifesta-se com muito mais acento a autonomia inerente ao EstadoFederado norte-americano. E, no sistema formal de produção legislativa da União, o Senado federal representa os interesses dos Estados, por meio de representantes eleitos diretamente e de forma igualitária, independentemente do número de habitantes e da extensão territorial. Nesse sentido, pode-se dizer que, nos EUA, se alcança um "Federalismo de política conjunta". 
Nesse modelo, seguido de perto pelo Brasil no que tange ao sistema senatorial, os senadores gozam de um mandato e são livres em suas decisões em relação aos Estados que representam. Não obstante, em nosso País, as alterações da Constituição são introduzidas com mais facilidade pelo Poder Legislativo Federal. Uma vez respeitado o quórum especial, para aprovação de emendas, mudanças prejudiciais aos Estados membros poderão ser introduzidas, ao arrepio dos interesses estaduais e municipais. Não se pode reconhecer, aqui, um federalismo de "política conjunta". O modelo, por nós adotado, pretensamente deveria criar a participação efetiva dos Estados Federados na elaboração das principais leis nacionais e propiciar a harmoniosa convivência de uma "política conjunta" entre a União e Estados membros que a integram. Não obstante, entre nós, tal matriz não funciona, estando os senhores senadores antes impactados pelas metas e políticas de seu próprio partido político em lugar dos interesses dos Estados que representam (em especial se o governador do Estado Federado pertencer a partido político diverso).

Por tais razões foi rejeitada, na Alemanha, a proposta de implantação de um Senado Federal nos moldes norte-americanos. Preferiu-se acolher um Conselho Federal composto por representantes dos Governos dos Estados (os Governadores e seus Secretários de Governo) que teria melhores condições de defender os interesses dos Estados. Os membros do Conselho Federal "não são eleitos, não possuem um mandato enquanto tais. Eles são nomeados através de decisão majoritária do governo estadual", e permanecem na condição de Conselheiros apenas enquanto mantiverem essa condição. ${ }^{15} \mathrm{O}$ Conselho desempenha, no entanto, funções análogas às do Senado Federal (como em nosso País), com destaque para a participação no processo legislativo, que constitui a sua principal tarefa. Há uma classe de leis "especiais" sobre as quais o Conselho Federal tem um poder absoluto de veto, e que devem necessariamente ser aprovadas por maioria absoluta no Conselho. As principais matérias dessas leis especiais são as seguintes:

a) leis que podem influenciar as finanças dos estados (...);

b) leis que afetem a soberania administrativa dos estados, isto é, a autonomia das administrações estaduais (...);

c) leis que tenham por objeto tarefas comuns da União e dos estados (...);

d) leis sobre o processo de alterações territoriais dos estados (...);

e) leis que são promulgadas em casos de emergência legislativa (...);

${ }^{15}$ SCHULTZE, Rainer-Olaf O. Federalismo na Alemanha. Fundação Konrad AdenauerStiftung: Traduções, n. 7, 1995, p. 77. 
f) leis que são promulgadas em situações de estado de defesa. ${ }^{16}$

$\mathrm{Na}$ Alemanha, o sistema jurídico garante, em medida superior à maioria dos Estados federais, uma participação efetiva dos Estados no processo legislativo federal. O Conselho Federal (de representantes dos Estados) atua com eficiência na construção das escolhas políticas mais importantes concernentes à elaboração das políticas públicas e até mesmo nos processos de emenda à Constituição e de escolha dos Juízes do Tribunal Constitucional Federal. Em linhas gerais, pode-se dizer que tanto na Alemanha quanto no Brasil há forte concentração da competência legislativa no âmbito da União. Mas na Alemanha a atuação legislativa dos Estados na formação das leis nacionais é efetiva(por meio do Conselho Federal) além de ficar a cargo dos Entes estaduais a implantação e arrecadação dos tributos em geral. ${ }^{17}$ Além dessas funções, o Conselho Federal desempenha ainda outras importantes tarefas, como as de participar da promulgação de decretos da União e regulamentos administrativos federais (funções executivas) e de eleger metade dos juízes integrantes do Tribunal Constitucional Federal.

Vejam a profunda quebra federativa que se dá, entre nós, na composição de nossa Corte Suprema: 4 ministros de São Paulo; 3 do Rio de Janeiro e 1 dos demais Estados do Sul/Sudeste; 1 de Mato Grosso. Nenhum, absolutamente nenhum, do Norte e do Nordeste. E não se diga que, nessas regiões, haveria ausência de bons juristas: Rui Barbosa, Aliomar Baleeiro, Otávio e João Mangabeira, Orlando Gomes, Seabra Fagundes, Pontes de Miranda e tantos outros. Vou me consentir citar apenas um jurista vivo: Ayres Brito, Sergipe. Todos do Nordeste. Tal desequilíbrio jamais aconteceria na Alemanha.

É claro que Juízes da Corte Suprema, que guardam a Constituição, seriam tocados pelos interesses nacionais e harmonia entre os Estados mais do que tudo. Não obstante, as mesmas razões que há para funcionar um Senado representativo dos Estados, há também para um Supremo federativamente balanceado. Entre tais razões, destaquemos duas: 1) juiz cria direito, daí que o Poder Judiciário é um Poder; 2) tal criação supõe, portanto, uma certa politicidade das decisões judiciais, no sentido

16 SCHULTZE, Rainer-Olaf O. Federalismo na Alemanha. Fundação Konrad AdenauerStiftung: Traduções, n. 7, 1995, p. 83.

17 Cf. L. J. HESSE. República Federal da Alemanha: do federalismo cooperativo à elaboração de política conjunta. In: SCHULTZE, Rainer-Olaf O. Federalismo na Alemanha. Fundação Konrad Adenauer-Stiftung: Traduções, n. 7, 1995, p. 117-138. 


\section{FEDERALISMO, LIBERDADE E DIREITOS FUNDAMENTAIS}

elevado do termo. Politicidade que Robert Dahl denunciou há tantos anos em seu precioso artigo, enfocando a Corte Suprema dos EUA. ${ }^{18}$

Percebe-se, portanto, que, no modelo alemão, afirma Klein, "não foram os estados, mas os parlamentos estaduais que perderam importância na estrutura de poder da República Federal da Alemanha", de modo que não houve qualquer ruptura em relação ao princípio federalista. ${ }^{19}$

Para exemplificar no Brasil, lembremos um dos problemas que mais abalam os Estados Federados no momento, a ausência das compensações devidas pela União aos Estados e Municípios, em decorrência das exonerações do ICMS nas exportações, advindas da Lei Kandir (Lei Complementar 87/96). Na Alemanha, isso jamais teria ocorrido. A omissão inconstitucional da União, do Congresso Nacional, em regular a matéria, omissão reconhecida por unanimidade na $\mathrm{ADO} \mathrm{n}^{\mathrm{o}} 25$, pelo Supremo Tribunal Federal, também nunca lá se teria realizado. Cedo, a tempo e hora, sem necessidade de intervenção do Supremo Tribunal Federal, os Estados exportadores estariam satisfeitos, por meio de justas compensações, previstas nas leis e na Constituição.

No Brasil, a difícil aprovação de leis complementares, é óbvio, pode ser manipulada pela bancada governista federal que sempre tem força suficiente para bloquear a aprovação de diplomas legislativos que não sejam de seu interesse. ${ }^{20}$ Se nosso Senado Federal representasse de fato

${ }_{18}$ DAHL, Robert A. Decision-Making in a Democracy: The Supreme Court as a National Policy-Maker. Journal of Public Law. n. 6, 1997, p. 279-295.

19 SCHULTZE, Rainer-Olaf O. Federalismo na Alemanha. Fundação Konrad AdenauerStiftung: Traduções, n. 7, 1995, p. 94.

20 Conforme explica BATISTA JÚNIOR, Onofre Alves. O projeto democráticodescentralizador da Constituição e o acerto de contas. Revista Consultor Jurídico. Disponível em: <http://www.conjur.com.br/2017-jun-27/onofre-junior-projetodemocratico-descentralizador-constituicao >. Acesso em: 28 jun. 2017: “Desde 2002, sobrevieram pelo menos dez projetos de lei complementar para alterar a sistemática de compensação na LC 87/96, além dos que foram apensados, e quatro propostas de Emenda à Constituição para assegurar o ressarcimento ou extinguir a desoneração do ICMS para produtos minerais primários ou semielaborados. Atualmente, pelo menos seis projetos de Lei Complementar e três PEC aguardam deliberação no Congresso Nacional - entre eles o mencionado PLP 02/99, que foi apensado ao PLP 221/98. Da análise dos dados acerca da tramitação dos principais projetos de lei e de propostas de emenda à Constituição que até hoje foram apresentados perante o Congresso Nacional, verifica-se que apenas dois projetos de lei complementar receberam pareceres pela sua aprovação na Comissão de Assuntos Econômicos do Senado Federal (CAE). Na 
os interesses estaduais, que deveriam representar, leis complementares já teriam disciplinado a matéria. Em lugar de uma federação de "política conjunta", temos uma política federal, unitariamente tomada pela União, imposta aos Estados sem as devidas compensações (embora obrigatórias, à luz das leis e da Constituição).

Do ponto de vista político, pois, o Federalismo se manifesta formalmente em pontos essenciais: a) em que os Estados-membros produzem a própria ordem jurídica, por meio de Poder Legislativo próprio, sendo de alta relevância a distribuição de competência entre eles; b) em que, ademais, participam da formação da ordem jurídica da União, ou por meio de um Senado, a exemplo dos modelos norte-americano e brasileiro, ou ainda por meio das funções exercidas por um Conselho Federal, à moda alemã.

Interessante observar que, no federalismo alemão, em que o Legislativo Estadual perde competência, em contrapartida, os Estados, por meio de seus executivos, participam mais ativamente da função legiferante da União. Cada um dos modelos federativos encontra seu equilíbrio em pontos distintos. A solução alemã repousa em um federalismo menos dualista do que o norte-americano, muito mais influenciado pela democracia social igualitária e, por tal razão, guiado, pelo menos no campo do Direito Social, pela ideia da necessidade de certa uniformidade, de se criarem oportunidades iguais para todos e de se garantir um padrão de vida mínimo similar em todos os Estados. Em compensação, lá se concede mais efetividade à participação dos Estados na formação das leis da União, assim como aos planos e projetos de política, evoluindo-se de um federalismo cooperativo para um governo de "política conjunta."

O fenômeno de mutação e transformação do Federalismo em geral não é isolado. Mas ele assenta-se em fundamentos de alta relevância, ressaltando dentre todos, a preservação da liberdade, metas e

Câmara dos Deputados, nenhum PLP conseguiu sequer obter parecer. Três PEC foram aprovadas na Comissão de Constituição e Justiça da Câmara, mas duas delas acabaram arquivadas ao final da legislatura. Também é de se notar que os relatores das Comissões instaladas, sempre pertenciam à base governista da Presidência da República no período de sua nomeação. Além disso, pode-se afirmar que todos os projetos e PEC apresentados sempre traziam como justificativa a necessidade de se buscar reverter as perdas decorrentes da desoneração do ICMS nas exportações instituída, em um primeiro momento, pela Lei Kandir (posteriormente elevada ao status constitucional pela EC 42/03). Seria mesmo uma ingenuidade acreditar que, sem a ADO, a força da União no Congresso Nacional (o "rolo compressor" legislativo), sobretudo na aprovação de leis complementares, pudesse ser transposta." 


\section{FEDERALISMO, LIBERDADE E DIREITOS FUNDAMENTAIS}

fundamentos que compensam as muitas dificuldades de sua manutenção. Importa antes, apesar das aparentes variações contínuas, compreender que há conceito de Federalismo, relativamente estável, do ponto de vista formal, feita abstração do conteúdo material das normas e competências. Mas difícil é a tarefa de buscar, em cada ordem jurídica, o Federalismo, sob o ângulo material (esse de acentuada variabilidade), ou seja, os pontos de equilíbrio e as competências, que, em extensão e quantidade, garantam suficiente autonomia e liberdade criadora aos entes federativos. Mas tanto a um conceito quanto a outro, somente se chega por meio de uma análise sistemática, jamais tópica ou restrita a certo aspecto isolado. Assim sendo a análise que se segue restringir-se-á à ordem jurídica nacional.

\section{Federalismo material e competência tributária}

Todo projeto ideal de reforma pressupõe um amplo debate público sobre o papel do Estado, seus deveres e encargos, distribuídos segundo as distintas esferas da Federação, os recursos financeiros a custearem encargos e serviços e a estratégia de desenvolvimento social e econômico a ser adotada. Tais definições são pressupostos que esbarram na ausência de um amplo debate nacional.

Histórica e tradicionalmente sabe-se que, nos Estados federativos, certas tarefas são atribuídas sempre à União, a saber, a defesa nacional, o comércio exterior, a defesa do comércio interno em mercado absolutamente integrado. Modernamente, grandes investimentos sociais de elevado custo como a previdência social p.ex. também costumam ser serviços federalizados. Assim aconteceu nos EUA, na Alemanha e no Brasil, embora em graus progressivos diferentes.

Quem lê os Artigos Federalistas ${ }^{21}$ observa que o poder tributário dos Estados era inquestionável, justificando os fundadores o poder atribuído à União nos malefícios advindos das cotas e requisições do sistema confederativo anterior. Argumentou Hamilton que um governo deve cumprir suas finalidades e serviços por meio de recursos financeiros próprios e adequados, sem necessidade de se socorrer da ajuda de outro. O enfraquecimento da União seria notável, se privada fosse do poder de tributar, assim como haveria perda para os Estados se houvesse delimitação do campo privativo de atuação. Preferiu, pois, a Constituição daquela nação trabalhar sem separação de fontes, atuando os Estados e a União concorrentemente, de forma cumulativa. Um único limite, de

${ }^{21}$ Cf. MADISON, James; HAMILTON, Alexander; JAY, John. Os Artigos federalistas 1787-1788: edição integral. Nova Fronteira, 1993. 
consagração secular e originária na Constituição norte-americana, realça a consciência de que o comércio exterior e a defesa do mercado interno são tarefas da União: a proibição de os Estados tributarem as importações e as exportações.

À luz desses princípios, no sistema americano superpõem-se tributos idênticos, utilizados por diferentes entes políticos (imposto de renda federal e estadual, e, em alguns casos, também municipal; imposto sobre heranças e doações federal e estadual). Mas as características do sistema tributário continuam assentadas no fato de que a receita da União é alimentada, sobretudo, por impostos incidentes sobre a renda e transferências de renda e a receita estadual, por imposto incidente sobre consumo (vendas).

O modelo tributário brasileiro seguiu certos aspectos desse sistema em que se inspirou: impostos de importação e exportação, assim como sobre a renda competem à União. Os Estados alimentarão as suas burras, tradicionalmente, em impostos sobre o consumo (vendas e consignações, depois, operações de circulação de mercadorias). Mas veremos que, em alguns pontos essenciais, afastou-se o Brasil do modelo norte-americano. Aos poucos foi banida a competência concorrente, presente nas primeiras cartas constitucionais de nosso País, para alicerçar-se o sistema na competência privativa, inibidora das bitributações. Os tributos sobre o consumo fixaram-se como plurifásicos e não cumulativos, em aproximação da experiência europeia. Mas, infelizmente, por longo período, continuaram os Estados tributando as exportações por meio de seu imposto de consumo - prática jamais utilizada pelos EUA e, pelo menos desde a $2^{a}$ e a $6^{a}$ Diretivas, proibida a todos os países da Comunidade Europeia.

O Federalismo alemão é fortemente influenciado pela democracia social, por normas de uniformização e equalização. $O$ poder de legislar sobre tributos está concentrado em mãos da União, embora os Estados detenham a competência residual e possam inventar um tributo novo. Em contrapartida, os Estados administram e arrecadam a quase totalidade dos impostos existentes naquela ordem jurídica. A redistribuição da receita aos Estados está fortemente ligada à meta de se garantir um padrão de vida digno a todo cidadão não importando o Estado em que se encontre. Mas como se viu, a solução alemã para equilibrar as relações entre os entes políticos, foi dar aos Estados uma forma mais efetiva de participarem do processo legislativo da União, por meio da atuação do Conselho Federal, integrado pelos executivos estaduais, que vetam ou aprovam as normas financeiras de seu interesse. Além disso, o sistema germânico encontra mecanismos de conciliação para solução de impasses, inexistentes em outros sistemas, assim como planos mais 


\section{FEDERALISMO, LIBERDADE E DIREITOS FUNDAMENTAIS}

intensos de cooperação e de coordenação dos Estados entre si e com a União que reduzem a sujeição, perturbadora da autonomia. A Corte Constitucional alemã vem coibindo a transferência de recursos da União a Estado, destinada a impor a observância de certo projeto ou plano federal. ${ }^{22}$

O Brasil, seguramente, tem seus próprios pontos de tensão, equilibrados de forma diferente dos demais Estados Federativos. Do modelo norte-americano, restou uma efetiva área de exercício da competência legislativa própria para os Estados e os Municípios, eliminada, porém, a competência concorrente (somente em matéria tributária) e outorgada a residual à União. Do modelo europeu, impregnado pela democracia social, colocou nossa ordem jurídica o Federalismo financeiro a serviço da erradicação da miséria e da pobreza e da redução das grandes desigualdades entre Estados, por meio de uma redistribuição da receita arrecadada em fundos de participação. Do ponto de vista da democracia social, a que se vincula o nosso Estado Democrático de Direito, a busca da justiça se assenta no dever de se favorecer a igualdade de oportunidades a todo cidadão e de propiciar a cada um uma existência digna, não importando o Estado Federado a que se vincule ou a comunidade regional a que pertença. Todos os Estados e a União entre si têm o dever recíproco e solidário de auxílio político, administrativo e financeiro, de modo que se reduzam substancialmente as grandes desigualdades regionais e locais. Não poderemos examinar aqui as causas da desigualdade resistente, que caracteriza o nosso País. ${ }^{23}$

${ }^{22}$ Cf. HESSE, Joachin Jens. República Federal da Alemanha: do federalismo cooperativo à elaboração de política conjunta. In: SCHULTZE, Rainer-Olaf O. Federalismo na Alemanha. Fundação Konrad Adenauer-Stiftung: Traduções, n. 7, 1995, p. 117-138.

${ }^{23} \mathrm{Um}$ dos indicadores da profunda desigualdade regional no Brasil é o IDH-M (índice de desenvolvimento humano médio), que sofre severa variação entre os Estados Federados. O Distrito Federal, por exemplo, possui o IDH-M mais alto do Brasil, no montante de 0,824, enquanto o Estado de Alagoas, que aparece em último lugar, tem IDH-M de 0,631. Para se ter uma noção, o IDH-M do Distrito Federal está acima do de países como Portugal $\left(0,822-41^{\underline{a}}\right.$ posição), Chile $\left(0,822-41^{\underline{a}}\right.$ posição) e Emirados Árabes Unidos ( 0,827 - 40aㅗ posição), enquanto o de Alagoas está abaixo do de países como Iraque $\left(0,642-120^{\underline{a}}\right.$ posição), Vietnã $\left(0,642-120^{\underline{a}}\right.$ posição) e Guiana $\left(0,638-121^{a}\right.$ posição). Fonte para o IDHM nos Estados Brasileiros: http://www.pnud.org.br/atlas/ranking/Ranking-IDHM-UF-2010.aspx ; para o ranking global: $\quad$ http://noticias.uol.com.br/infograficos/2014/07/22/brasil-fica-em-79-noranking-mundial-de-idh-veja-resultado-de-todos-os-paises.htm . Acesso em 10 de setembro de 2014. 
Como é sabido e não importa repetir, a Constituição de 1988 representa a culminância de um processo de abertura política já lentamente iniciado, para o restabelecimento da vida democrática nacional. Para atender a uma série de serviços públicos relevantes, a cargo de Estados e Municípios, como não poderia deixar de ser, a Constituição cuidou de reforçar o federalismo, como garantia adicional da liberdade, tanto do ponto de vista do poder de legislar, ou seja, das competências, como do ponto de vista financeiro. Primeiro, a Constituição cuidou de aumentar o espaço legislativo dos Estados, do Distrito Federal e dos Municípios. Em relação ao Direito Tributário, impostos, antes atribuídos ao campo de competência da União, passaram ao Poder Legislativo estadual, como o incidente sobre serviços de transporte intermunicipal e interestadual e de comunicação, sobre minerais, combustíveis líquidos e gasosos e energia elétrica. Além disso, o imposto incidente sobre a transmissão causa mortis e doação de quaisquer bens ou direitos, como espécie nova, foi conferido aos Estados-membros. Finalmente, a Carta de 1988 permitiu aos entes estaduais, até o advento da Emenda Constitucional no. 03/93, criar adicional ao imposto de renda pago à União. Dois outros impostos compuseram, na redação original da Constituição, o elenco dos tributos de competência municipal, a saber, o de transmissão intervivos, a qualquer título por ato oneroso, de bens imóveis e o de vendas de combustíveis no varejo, esse último também extinto pela mesma Emenda Constitucional no 3/93. Finalmente, a Constituição de 1988 veda à União conceder isenção de tributos estaduais e municipais, reforçando assim a autonomia dos entes políticos da Federação. Os Fundos de participação de Estados e Municípios ainda compõem o quadro da distribuição da recita dentro das metas de construção de um Estado Democrático de Direito.

Então, ao conferir maior renda tributária a Estados, Distrito Federal e Municípios, quer por meio da participação de um ente estatal no produto da arrecadação de outro, quer pela participação em fundos de redistribuição, quer pela atribuição mais lata de competência tributária, a Constituição dotou-os de maior autonomia política, legislativa e financeira.

Portanto, o Federalismo financeiro nacional repousa na ideia de que as competências tributárias conferem aos entes estatais - pelo menos à União e aos Estados - receita suficiente (e até excedente) para a manutenção dos serviços e finalidades públicas que lhes são atribuídos. Cada ente público deve criar os tributos que lhe foram destinados pela Constituição, arrecadá-los e administrá-los, sendo essa receita, em princípio, garantidora da governabilidade de cada pessoa estatal. Os excedentes devem ser redistribuídos para os entes estatais dotados de 
menor extensão territorial - em que os fins de equalização são predominantes - (da arrecadação da União devem verter recursos para os Estados e Municípios; dos meios financeiros atribuídos aos Estados, parcela deve ser canalizada para os Municípios). A redistribuição de tais recursos obedece a critérios diversificados, mas a necessidade é dos mais relevantes, de tal sorte que, além de um fundo especial destinado a favorecer os Estados do Norte, Nordeste ou Centro-Oeste, criado pela Constituição, cerca de 85\% dos recursos do Fundo de Participação dos Estados e do Distrito Federal são canalizados para aquelas mesmas regiões mais pobres do País (Lei Complementar $n^{\circ}$. 62/89) e apenas $15 \%$, destinados ao Sul-Sudeste. ${ }^{24}$

Entretanto, como já ressaltamos, o conceito de Federalismo resulta de uma análise global da ordem jurídica. Nesse aspecto, os pontos de equilíbrio, em nosso País, têm sido profundamente alterados por emendas e leis infraconstitucionais, de tal sorte que Estados e Municípios têm sido forçados, em decorrência da atual situação financeira ruinosa em que se encontram, ou a aderir a uma política federal de projetos e propostas ou a custear os apertos de caixa do Tesouro nacional. Tal contexto não pode ser esquecido, no momento de se decidir, por exemplo, se o ICMS ${ }^{25}$, como maior e mais produtivo tributo da América Latina, deve permanecer no campo de competência dos Estados ou migrar para a União, acentuando-se a já insuportável centralização de poder. Examinemos rapidamente alguns dos mecanismos atuais, engendrados pela União para centralizar recursos e poder em suas mãos.

\section{O DESEQUILÍBRIO OFENSIVO AO FEDERALISMO CONSTITUCIONAL, NA HORA PRESENTE}

A Constituição Federal contém mecanismos para solução de crises financeiras, para pagamento de dívidas de um ente político e para composição de conflitos entre Estados e Municípios e destes com a União. Tais soluções, entretanto, não passam por uma conciliação institucionalizada das crises. Supõe-se, por ex., que o Senado Federal, sendo a Câmara Alta do Congresso Nacional pudesse desempenhar além de suas precípuas funções de legislar - esse papel, o que não se

\footnotetext{
${ }^{24}$ Como já acentuamos, somente o exame aprofundado de nossas circunstâncias poderia explicar a persistência das grandes desigualdades regionais, entre grupos e indivíduos. Ver nota 23 supra.

25 Ver PRADO, Sérgio Prado. Equalização e Federalismo Fiscal- Uma análise comparada: Alemanha, Índia, Canadá, Austrália, Brasil. Rio de Janeiro: Fundação Konrad Adenauer, 2006, 463 p.
} 
mostrou factível em razão da priorização que confere aos partidos políticos a que se filiam os senadores, em lugar dos interesses dos Estados membros.

A desorganização das finanças estaduais, a desobediência à Constituição e ao cumprimento das decisões judiciais, assim como a suspensão injustificada do pagamento da dívida fundada, por dois anos consecutivos, autoriza a intervenção federal nos Estados. (Art. 34 da Constituição Federal). Mas a intervenção não teria como objetivo estrangular o Estado ou Município, ao contrário, destinar-se-ia a viabilizar o Ente estatal, com possível canalização de recursos federais àquele Ente com vistas à regularização de suas finanças e contas.

Para socorrer o pagamento de créditos de um ente político em relação a outro, a Constituição Federal estabeleceu o controvertido art. 160 e parágrafo único, outorgando ao credor o direito de retenção de transferências. Mas tal dispositivo não pode ter o sentido extensivo que lhe dá a União, quando se trata de satisfazer os seus créditos. Cumpre destacar que

(a) Outro é o sentido da expressão vincular e equiparar a expressão constitucional condicionar a entrega de recursos a compensação fere nosso próprio Código Civil, que expressamente veda essa forma de extinção com coisa não suscetível de penhora, como receita pública;

(b) finalmente, não importam os limites e a extensão da interpretação atribuída ao art. 160, é certo que ele não pode se referir a créditos unilateralmente apurados, atualizados, liquidados e satisfeitos pelo próprio credor, sem que o Estado devedor possa, pelo menos em procedimento administrativo, a que a Constituição assegura ampla defesa, expor as justificações do inadimplemento, como força maior, onerosidade excessiva ou estado de necessidade.

Mas o art. 160 é o único mecanismo existente na Constituição Federal que foge ao art. 100, ou seja, aquele que consagra a satisfação dos créditos (independentemente da pessoa de seu titular, pessoa pública ou privada ou natural), já reconhecidos por decisão passada em julgado, pela via dos precatórios. (A recente exceção para créditos de pequeno valor somente confirma a regra). A solução do art. 160 repousa na ideia de que as transferências de tributos de alheia competência destinam-se a equalizar e a reduzir desigualdades existentes entre os Entes políticos da Federação e que o exercício da competência para cobrança dos tributos próprios de 
cada um seria suficiente para garantir a governabilidade. Mas a ideia é discutível, pois há pequenos Estados da Federação e muitos Municípios, que não sobreviveriam sem suas cotas dos fundos de participação, exatamente esses os mais necessitados dos recursos transferíveis.

Finalmente, as causas e os conflitos surgidos entre a União e os Estados, constitucionalmente, devem ser processados e julgados originalmente pelo Supremo Tribunal Federal, de acordo com o art. 102, I, f. Inexistem comissões de mediação como no Direito alemão. Nem tampouco um Conselho Federal, à moda dos germanos, composto dos executivos dos governos estaduais. Muitas vezes, além disso, aqui no Brasil, como já fartamente referido, o Senado Federal, antes premido pela política partidária do que por suas funções institucionais de representação dos Estados, recusa-se até mesmo a ouvir queixas ou dificuldades financeiras graves de governantes, politicamente não alinhados.

Entretanto, na hora presente, abala-se a República e rompem-se profundamente os alicerces da concepção federalista. Os pontos de equilíbrio, previstos na Constituição de 1988, foram alterados por leis infraconstitucionais e mesmo contratos, implantando-se ou tentando implantar-se o mais forte centralismo das últimas décadas. Brevemente, podemos citar, entre outros, alguns fatos representativos, a título exemplificativo:

(a) planos políticos, impostos pela União, são aprovados sem lei nacional de ampla discussão, obrigatórios para os Estados (à vista da insuficiência de sua representação política senatorial)cogentes por meio de sanções pecuniárias graves, além de autorização de empréstimos que criam dependência. Na verdade, os Estados foram obrigados, para celebrar o contrato de confissão e refinanciamento de dívidas com a União, a firmar antes um "Protocolo de Acordo", dentro do Programa de Apoio à Reestruturação e ao Ajuste Fiscal dos Estados. Tal programa de metas se consubstancia, na realidade, em um voto do Ministro Pedro Malan no Conselho Monetário Nacional, segundo o qual se desenvolve uma política de alienação de ativos ou privatizações, concessões de serviços públicos, redução de servidores com saneamento das despesas. E mais, inexistiu lei nacional de fixação de plano econômico, por meio de normas gerais, como preceitua o art. $24, \S 1^{\circ}$. da Constituição. Mas a Lei 9.496, de 11 de setembro de 1997, a ele se refere brevemente, nominalmente, sem descrição ou regulação direta. Do ponto de vista jurídico não estariam obrigados os Estados a seguir as diretrizes federais, não obstante o Estado de Minas Gerais tê-las adotado e fielmente implantado, pelo menos em relação à privatização da CEMIG, uma das maiores empresas de energia elétrica da América Latina - privatização felizmente revertida desde 
1999/2000; mais recentemente, Estados em dificuldades financeiras (como ocorreu com o Estado do Rio de Janeiro), para alcançarem socorros financeiros federais tiveram de aderir compulsoriamente a programas de privatização federais, além de outras metas e normas administrativas impostas;

(b) atos de expropriação das receitas próprias dos Estados, já recolhidas aos cofres públicos. Contratos de renegociação das dívidas dos Estados foram firmados com a União, premidos que estavam os Estados membros por situação financeira ruinosa. A responsabilidade da União pela insolvência de vários Estados é patente, pois a política de juros elevadíssimos, além de desencadear desemprego e recessão, aumentou progressivamente a dívida pública. Em tais circunstâncias, a União firmou contrato com os Estados, assumindo-lhes as obrigações. Não obstante, sujeitou-os a cláusulas de alienação da receita (que é absolutamente inalienável), inclusive e especialmente, da receita própria dos Estados membros, arrecadada e entesourada não simplesmente transferida, sem nenhuma autorização constitucional, bastando para isso o não pagamento; tais contratos, que estão em discussão no Supremo Tribunal Federal, confundem a possibilidade excepcional de vinculação da receita à despesa com as obrigações da dívida, autorizada no art. 167, IV,$\S 4^{\circ}$, da Constituição, com garantia real e sequestro extrajudicial; autorizam, assim, consequente execução extrajudicial sumária, sem prévia notificação ao devedor, com formação, apuração, liquidação e satisfação do crédito, exclusivamente pelo credor, sem sequer prévio procedimento administrativo, assentado no direito amplo de defesa e no devido processo legal; ofendem o art. 100, assim como os arts. $1^{\circ}, 2^{\circ}, 23$, $24 \S 4^{\circ}, 25,34,60 \S 4^{\circ}$, e 168, todos da Constituição Federal, causando graves e irreparáveis lesões, ferindo a autonomia do Estado e, em muitos casos, inviabilizando-o financeiramente, para privar milhões de brasileiros de serviços públicos essenciais, tudo em nome de plano acertado e concertado alhures. A dependência e a subserviência prolongar-se-ão por décadas... posteriormente, a Lei de Responsabilidade Fiscal, em desrespeito à Constituição da República, autorizou a prestação de garantias e contra garantias, cujo descumprimento acarreta a expropriação da receita do Ente estatal devedor, ou seja a execução sumária da dívida.

Como os demais Estados da Federação, o Estado de Minas Gerais firmou com a União Federal, em 26 de setembro de 1.996, " Protocolo de Acordo", através do qual fixaram as partes acordantes as diretrizes para a renegociação das dívidas estaduais, dentro do Programa de Apoio à Reestruturação e ao Ajuste Fiscal dos Estados. Como consequência do citado "Protocolo", celebraram posteriormente o "Contrato de 


\section{FEDERALISMO, LIBERDADE E DIREITOS FUNDAMENTAIS}

Confissão, Promessa de Assunção, Consolidação e Refinanciamento de Dívidas " (Contrato ${ }^{\circ}$ 004/98/STN/COAFI), parcialmente nos moldes do previsto pela Lei $\mathrm{n}^{\circ}$ 9.496, de 11 de setembro de 1.997, e do estipulado pela Resolução $n^{\circ}$ 99/96, do Senado Federal.

O referido contrato estabeleceu garantias reais de execução sobre as receitas tributárias do Estado, concedendo poderes à União de auto execução extrajudicial e expropriação, em afronta direta aos mais elementares e básicos princípios constitucionais norteadores do pacto federativo. Em verdade, norteou-se o contrato pelo que consta, hoje, do inciso II do $\S 1^{\circ}$ do art. 40 da Lei de Responsabilidade Fiscal, embora não houvesse, para a expropriação da receita de impostos estaduais, lei autorizativa estadual e nem tampouco resolução senatorial expressa, instrumentos que se limitaram a consentir em uma vaga vinculação da receita. (Cf. Lei estadual $\mathrm{n}^{\circ}$ 12.422, de 27 de dezembro de 1996; Lei Federal no. 9496, de 11 de setembro de 1997 e Resolução no‥ 99.96, do Senado Federal).

Em caso de descumprimento pelo Estado de quaisquer obrigações assumidas no contrato $\mathrm{n}^{\circ}$ 004/98, firmado com a União, com intervenção do então Banco do Estado de Minas Gerais (na qualidade de depositário) e do Banco do Brasil S/A (na qualidade de agente), gravíssimas consequências são desencadeadas. Vão desde multas moratórias, à substituição dos encargos financeiros contratuais por encargos equivalentes ao custo médio de captação da dívida mobiliária interna do Governo Federal, ao aumento da vinculação da receita líquida estadual ao pagamento até o vencimento integral da dívida e, finalmente, às expropriações das receitas próprias do Estado e por ele arrecadadas, que devem ser centralizadas em conta única à disposição da União. Tais apropriações vêm complementadas com retenções das parcelas devidas ao Estado, por meio do Fundo de Participação ou das cotas de compensação, decorrentes da Lei Complementar 87/96. ${ }^{26}$

${ }^{26}$ Confira as seguintes cláusulas contratuais:

Cláusula Décima-Sétima: O Estado se obriga, durante toda a vigência deste Contrato, a manter conta de depósitos no Agente, suprindo-a com recursos suficientes à cobertura dos compromissos decorrentes deste Contrato em seus vencimentos, e autoriza o Agente, em caráter irrevogável e irretratável, independentemente de qualquer aviso ou notificação, a efetuar débitos na conta no. 42.117-0, agência 033-7, e, caso esses recursos não satisfaçam a totalidade do débito, o Estado autoriza o Depositário, em caráter irrevogável e irretratável, a transferir ao Agente, mediante débito à conta de centralização de receitas próprias do Estado, Agência 002-6, Cidade 
Tal contrato de confissão, assunção e refinanciamento de dívida tem a natureza de contrato da "Administração Pública" (na feliz terminologia adotada por Lúcia Valle Figueiredo ${ }^{27}$ que tanto se submete às normas básicas do direito privado, como ainda, em muitos aspectos essenciais, às normas fundamentais do direito público. Sobretudo, sujeita-se às normas da Constituição.

de Belo Horizonte, conta corrente no. 127.000-8, quantias suficientes à liquidação das obrigações financeiras ora pactuadas.

Parágrafo único - O Estado se compromete a manter a conta de centralização de receitas referidas no caput e a somente substituir a instituição depositária após comunicação à União, por intermédio da Secretaria do Tesouro Nacional, e ciência do Agente, e desde que a nova instituição depositária se manifeste formalmente de acordo com os termos deste Contrato, no que se refere às obrigações do Depositário.

Cláusula Décima-oitava - O Estado, devidamente autorizado pelas Leis Estaduais nos. 12.422, de 27.12.96, 12.731, de 30.12.97 e 12.746, de 8.1.98, transfere à União, mediante cessão, condicionada à ocorrência de inadimplemento das obrigações ora pactuadas, a título pro solvendo, os recursos provenientes das receitas de que tratam os arts. 155, 157 e 159, incisos I, alínea a, e II, da Constituição, até os montantes devidos e não pagos, inclusive encargos, e, neste ato, confere poderes, em caráter irrevogável e irretratável, à União, por si ou por intermédio do Agente, para:

I - transferir as cotas das receitas tributárias a que se refere o artigo 159 da Constituição, creditadas no Banco do Brasil S/A, Agência 033-7, cidade de Belo Horizonte, conta corrente no. 42.117-0; e II - requerer a transferência de recursos até o limite do saldo existente, da conta de centralização de receitas próprias do Estado no Depositário, Agência 002-6, cidade de Belo Horizonte, conta corrente no. 127.000-8; III- transferir as cotas das receitas tributárias a que se refere o item 1 do anexo à Lei Complementar $\mathrm{n}^{\circ}$ 87, de 13 de setembro de 1996, creditadas no Banco do Brasil S/A, Agência no. 033-7, cidade de Belo Horizonte, conta-corrente no. 42.117-).

Parágrafo primeiro - Para efetivação da cessão e transferência a que se refere esta cláusula, a União, por si ou por intermédio do Agente, informará ao Depositário, o valor da importância a lhe ser transferida.

Parágrafo segundo - O Estado se obriga a adotar, no âmbito de sua competência, as medidas necessárias para complementar as garantias ora ajustadas, mediante solicitação justificada da União.

Parágrafo terceiro - O Depositário se obriga, neste ato, em caráter irrevogável e irretratável, a transferir, no prazo máximo de 1 (um) dia útil, até o limite dos saldos existentes, mediante requisição da União ou do Agente, os valores necessários ao pagamento das obrigações decorrentes deste contrato, sob pena de multa diária de $1 \%$ (um por cento) do valor requisitado.

27 Cf. FIGUEIREDO. L. Valle. Curso de Direito Administrativo. 2 ed. São Paulo: Malheiros Editores, 1995, p. 239. 
Sendo misto o regime jurídico, o princípio federal, que repousa na absoluta igualdade de direitos entre os Estados, na autonomia e nos deveres recíprocos da União e dos Estados de lealdade, ajuda e solidariedade, assim como a inalienabilidade e impenhorabilidade dos bens públicos estaduais (especialmente da receita pública), afetados que estão aos superiores interesses dos serviços públicos da coletividade, são aspectos públicos essenciais que imprimem peculiaridades ao princípio privatístico do pacta sunt servanda. Evidentemente, todo contrato, mesmo de direito privado - e esse não é o caso, deve respeitar as normas fundamentais da Constituição. Será o contrato referido norma superior à Constituição Federal?

A questão assume especial relevância em época de recessão econômica, em que as previsões orçamentárias de arrecadação não se concretizam, ficando a receita real muito inferior à estimada. De acordo com farta documentação, consubstanciada em relatórios contábeis e financeiros preparados pelos órgãos competentes da Administração Estadual e devidamente auditados e registrados em Relatório Técnico, elaborado pelo Tribunal de Contas do Estado, comprovou-se que a situação do Estado de Minas Gerais era, em janeiro de 1999, lamentavelmente, de inequívoca insolvência. O Estado de Minas Gerais estava em verdadeiro estado de necessidade administrativo. Nesse contexto, os bloqueios de recursos e as intervenções federais em contas bancárias do Estado provocaram profundo desgoverno e, eventualmente, o descumprimento involuntário de uma ou outra norma constitucional (por exemplo, aquela que fixa data mensal para o repasse das receitas dos demais Poderes), pagamento de precatórios, etc..

Ao recorrer ao Supremo Tribunal Federal (Medida Cautelar, PET1665), o Estado de Minas Gerais não pretendeu anular o contrato, ao contrário, pretendeu honrá-lo, dele, porém, expurgando as inconstitucionalidades patentes. Submeteu as principais peças processuais e documentos que as lastrearam aos mais importantes juristas do País, obtendo deles, de forma gratuita e generosa, os mais brilhantes pareceres, em adesão e ressonância à voz de Minas Gerais. Em verdade, nenhum jurista consultado recusou seu apoio. Mas, invariavelmente, constitucionalistas e administrativistas consagraram as teses do Estado de Minas Gerais em defesa do federalismo, da solidariedade e da lealdade entre os entes da Federação, assim como apontaram a inconstitucionalidade daquelas cláusulas contratuais que admitem gravar as receitas públicas arrecadadas, de ônus reais, autorizando a execução direta, extrajudicial da dívida.

Pronunciaram-se em favor do Estado de Minas Gerais e reconheceram a inconstitucionalidade dos bloqueios os seguintes juristas e professores, 
em pareceres formalmente elaborados: Aloízio Gonzaga De Andrade Araújo (UFMG); Lúcia Valle Figueiredo (PUC-SP); Américo Masset Lacombe (PUC-SP); Dalmo De Abreu Dallari (USP); Eros Roberto Grau (USP); Fábio Konder Comparato (USP); Menelick De Carvalho Netto (UFMG); Celso Antônio Bandeira De Mello (PUC-SP); José Alfredo De Oliveira Baracho (UFMG); Sebastião Alves Dos Reis (UFMG). ${ }^{28}$

Infelizmente, tais bloqueios e execuções sumários têm sido praticados pela União, continuamente até a data de hoje, em violação à Constituição e aos direitos e garantias fundamentais dos cidadãos. Como exemplos, lembremos as recentes intervenções no caixa do tesouro dos Estados do Rio Grande do Sul e do Rio de Janeiro. Sobre a indisponibilidade da receita tributária do Estado, afetada às prioridades constitucionais de se prover a segurança, a saúde e a educação do povo que habita o seu território, manifestam-se claramente nossos juristas. Por todos, citemos Dalmo de Abreu Dallari: ${ }^{29}$

Assim, por exemplo, de acordo com a Constituição brasileira os Estados são obrigados a proporcionar ao povo que vive no seu território educação, cuidados de saúde, segurança pública, serviços judiciários, devendo ainda manter um sistema penitenciário, uma rede viária e outros serviços básicos, que, obviamente, pressupõem a existência de um corpo de servidores remunerados, além do que são obrigados, também a manter uma Assembleia Legislativa. Do ponto de vista jurídico, a essas obrigações dos governantes correspondem direitos dos governados, que os governadores devem atender, sob pena de serem responsabilizados por via judicial por falta de cumprimento de um dever legal. Assim, por exemplo, o cidadão de um Estado que tiver filho em idade escolar pode mover ação judicial contra o governador se não for assegurada uma vaga para que seu filho possa estudar. O funcionalismo do Estado tem direito à remuneração, podendo exigir judicialmente o atendimento desse direito.

28 Ver reprodução completa de cada um deles na Direito Público: Revista da Procuradoria Geral do Estado de Minas Gerais. Belo Horizonte: Del Rey Ed., n. 1, vol. 1.

${ }^{29}$ Cf. Revista da Procuradoria Geral do Estado de Minas Gerais. Belo Horizonte: Del Rey Ed., n. 1, vol. 1, p. 82. 
Em conclusão, a obrigação de manter os serviços e satisfazer as exigências que decorrem de imposições constitucionais são as prioridades dos governos estaduais, quanto à destinação dos recursos financeiros de que dispuserem. Outros encargos, ainda que decorrentes de contratos ou acordos celebrados com particulares ou entidades públicas, ficam em plano secundário. A impossibilidade de atendê-los, por falta de recursos financeiros, não deve acarretar qualquer consequência jurídica, pois estará claramente caracterizada uma hipótese de força maior.

Na situação atual do Brasil, quando se sabe que os Estados tiveram reduzidas suas possibilidades de arrecadação e que isso se deve à política econômica e às diretrizes financeiras adotadas pelo Chefe do Executivo federal, seria antijurídico, inconstitucional e injusto deixar de cumprir a obrigação constitucional de dar prioridade aos direitos do povo para atender às demandas de recursos financeiros do governo federal.

São unânimes nossos juristas em evidenciar que tais cláusulas contratuais firmadas e, consequentemente, os dispositivos da Lei de Responsabilidade Fiscal são ofensivos ao Federalismo, consagrado em nossa Constituição como cláusula pétrea. Acrescenta Fábio Konder Comparato, forte em Hans-Jochen Vogel, que a autonomia dos Estados Federados tem como seus corolários, a harmonia federativa e o princípio do comportamento federal amigável 'GrundsatzbundesfreundlichenVerhaltes', concluindo que os bloqueios de recursos do Estado de Minas Gerais, praticados pela União, representaram verdadeiro abuso. Enfim,

O mandado irrevogável e irretratável de transferência de saldos em conta bancária para efeito de pagamento, estipulado na cláusula décima-sétima do mesmo contrato, fere os princípios da autonomia federativa e da justiciabilidade na solução dos conflitos de interesse entre unidades federadas. ${ }^{30}$

${ }^{30}$ Cf. Revista da Procuradoria Geral do Estado de Minas Gerais. Belo Horizonte: Del Rey Ed., n. 1, vol. 1, p. 100. 
Em realidade, o inciso II do $\$ 1^{\circ}$ do art. 40 da Lei Complementar 101/2000 é uma tentativa, vã, de constitucionalizar ou de legalizar os contratos firmados entre a União e os diversos Estados da Federação, nessa parte. Vã, pois é elementar que uma lei complementar de normas gerais é hierarquicamente inferior à Constituição e não pode modificá-la ou expandi-la.

Nesse passo é bom citar o exemplo da Alemanha, país que adota um federalismo de franca interdependência. Sobre essa questão já teve oportunidade de se pronunciar o Tribunal Constitucional alemão, a fim de rechaçar as tentativas da União de conduzir a política dos Estados, por meio de transferências condicionadas de recursos. Comentando o fato, assim se expressa Heinz Laufer:

Por meio de ajudas da federação para o investimento, o governo federal conseguiu obter possibilidades consideráveis de influenciar a política dos estados e dos municípios, pois nem sempre ele observa a fidelidade à letra das determinações contidas no art. 104a, §4 da Constituição. As suas ajudas financeiras são utilizadas ocasionalmente como instrumento para o controle direto ou indireto dos investimentos, para fins de imposição de objetivos genéricos de política econômica, política monetária, política de planejamento regional ou política estrutural do governo federal nos estados; elas estão vinculadas a condições ou exigências ligadas às dotações e têm tendência de restringir a liberdade de planejamento e de projeto dos estados. Isso restringe consideravelmente a liberdade decisória dos estados da República Federal da Alemanha; eles se tornam ainda mais dependentes do governo federal, sofrem como que uma heterodeterminação e se transformam com excessiva facilidade em "pensionistas do governo federal".

O Tribunal Constitucional Federal, invocado pelo Estado Livre da Baviera, bloqueou esse desenvolvimento que ameaça o ordenamento federativo, na medida em que decidiu que as ajudas financeiras, a partir do orçamento federal devem continuar sendo exceções e que a sua concessão seja regulamentada juridicamente de tal forma que elas não se possam tornar um meio de obtenção de influência sobre a liberdade decisória dos estados no cumprimento 


\section{FEDERALISMO, LIBERDADE E DIREITOS FUNDAMENTAIS}

das tarefas que lhes incumbem. O Tribunal Constitucional decidiu ainda, mais especificamente, que deveria ser excluída a possibilidade de que esses subsídios do governo federal, fora dos objetivos de fomento, previstos no Art. 104a,$\S 4$ da Constituição, permitissem a obtenção de influência sobre o cumprimento das tarefas pelos estados, a partir da ótica da política do governo federal. Por conseguinte a lei, para a qual o consentimento expresso do Parlamento Federal é exigido, conforme as determinações do Art. $104^{\mathrm{a}}$, §4 da Constituição, deveria conter tudo o que fosse necessário e não poderia abandonar nada aos regulamentos administrativos nem às decisões discricionais de um ministério e muito menos ainda à mera práxis da administração pública. O Tribunal Constitucional Federal decidiu que sobretudo as condições e as exigências do governo federal de tipo financeiro ou técnico, vinculadas às dotações, seriam inadmissíveis quando tivessem por objetivo vincular a liberdade decisória dos estados a interesses e intenções da política federal (Decisões do Tribunal Constitucional Federal 39, 96 ss.)." 31

(c) política sistemática de redução das receitas estaduais e municipais, por diferentes mecanismos, inclusive transferências de ônus e déficits da União, que passam a serem custeadas pelas demais pessoas estatais. Contrariando o sentido originário da discriminação da receita, estabelecido na Constituição de 1988, que optou por uma descentralização políticofinanceira, por meio de sucessivas reformas, concentraram-se novamente os recursos no governo central. Para financiar seus próprios déficits, a União criou o Fundo de Estabilização Social, depois Fiscal - FEF - ; em seguida, emendou a Constituição para que, sucessiva e repetidamente, desvios da aplicação dos recursos advindos das constituições sociais e outros tributos, antes destinados obrigatoriamente ao custeio da Seguridade Social (e outras finalidades sociais) fossem autorizados na chamada desvinculação da receita da União; em seguida, a Lei Complementar 87/96, a fim de garantir o equilíbrio da balança comercial, reduziu significativamente a arrecadação dos Estados nas exportações, para que uma política teimosa de câmbio rígido, que acabou fracassando,

31 SCHULTZE, Rainer-Olaf O. Federalismo na Alemanha. Fundação Konrad AdenauerStiftung: Traduções, n. 7, 1995, p. 145-146. 
pudesse sobreviver; a União não honrou as necessárias compensações previstas em lei e depois inseridas na Constituição - decorrentes das desonerações das exportações nacionais, altamente prejudiciais na arrecadação do ICMS, tributo mais relevante no custeio das atividades dos Estados membros; e, finalmente, a fim de sanear a Previdência Social e cobrir os seus déficits, a União fez aprovar a Emenda Constitucional $n^{\circ}$. 20, com base na qual, supostamente, mas sem lei expressa, portarias, circulares e ordens de serviço do INSS pretendem equiparar Estados e Municípios a empregadores e empresas, assim como servidores públicos, não ocupantes de cargo efetivo, a empregados, para constituir créditos tributários contra os Estados, sujeitando-os a sanções e elevadas multas. E mais, a intenção é impor-lhes ainda uma execução direta, extrajudicial, por meio de retenções, supostamente autorizadas pelo parágrafo único do art. 160 da Constituição.

Convém destacar, nesse item, que a amputação financeira dos recursos dos Estados membros perpetrada pela União corresponde sempre a descumprimento de obrigação legal e constitucional. Em 1996, o legislador complementar promoveu a desoneração completa do ICMS nas exportações, por meio do art. 3o, II, da LC 87/96 (a chamada "Lei Kandir"), ${ }^{32}$ ou seja, excluiu, também, da incidência do ICMS a exportação dos produtos primários e dos semielaborados, estabelecendo, desde então, a compensação aos Estados pela perda de arrecadação. ${ }^{33}$ A EC 43/2003 procedeu à sua convalidação, entretanto, as compensações necessárias, nos moldes determinados, nunca foram suficientes e a lei complementar prevista nunca foi editada pela União. Nesse passo, o STF aprovou, por unanimidade, a fundação da decisão que reconheceu a inconstitucionalidade da omissão. Nas palavras do Ministro Gilmar Mendes, relator, verbis:

Não há dúvidas de que a partilha das receitas, especialmente de impostos, é uma questão fundamental do pacto federativo brasileiro, assim como de qualquer

\footnotetext{
${ }^{32}$ Art. 3․ O imposto não incide sobre:[...]II - operações e prestações que destinem ao exterior mercadorias, inclusive produtos primários e produtos industrializados semielaborados, ou serviços.

${ }^{33}$ Art. 31. Até o exercício financeiro de 2.002, inclusive, a União entregará mensalmente recursos aos Estados e seus Municípios, obedecidos os limites, os critérios, os prazos e as demais condições fixados no Anexo desta Lei Complementar, com base no produto da arrecadação estadual efetivamente realizada do imposto sobre operações relativas à circulação de mercadorias e sobre prestações de serviços de transporte interestadual e intermunicipal e de comunicação no período julho de 1995 a junho de 1996, inclusive.
} 


\section{FEDERALISMO, LIBERDADE E DIREITOS FUNDAMENTAIS}

Estado fiscal que se estruture na forma de federação. De nada adianta o zelo na partilha de competências constitucionais, entre os diferentes entes federativos, se essa repartição não é acompanhada da divisão de recursos próprios e suficientes para fazer frente às diversas tarefas que lhes foram conferidas pelo Poder Constituinte. As competências constitucionais esvaziam-se sem as condições materiais para o seu exercício. [...] $\mathrm{O}$ rearranjo político promovido pela Constituição Federal de 1988 foi impulsionado por duas grandes forças. De um lado, a luta por descentralização política e garantia de autonomia aos entes subnacionais, especialmente os municípios. De outro, o desejo de ampliação do elenco de direitos fundamentais constitucionalmente assegurados, especialmente os direitos sociais, e de torná-los universais para todos os brasileiros. Esses dois elementos foram componentes preponderantes para o desenho do quadro fiscal ainda hoje vigente na Constituição. [...] A luta por autonomia política por parte de estados e municípios iria necessariamente afetar a partilha de recursos públicos. A desejada autonomia política não poderia existir sem que estivesse aliada à autonomia financeira, e esta, no contexto de um Estado fiscal, depende, fundamentalmente, da divisão de competências tributárias e da partilha do produto da arrecadação tributária. [...] Parece correto afirmar, nesse sentido, que as duas décadas que sucederam à promulgação da Carta de 1988 caracterizaram-se pela inversão do quadro de partilha de receitas traçado na Constituinte. [...]

(Ação Declaratória de Inconstitucionalidade por Omissão, nํ25).

(d) prosseguindo no tema da redução dos recursos disponíveis para Estados e Municípios, lembremos que a União tem praticado uma série de manobras de tal modo que a receita própria daqueles Entes estatais reste reduzida. Já realçamos acima, a desoneração completa do ICMS nas exportações, por meio do art. $3^{\circ}$, II, da LC87/96 (a chamada "Lei Kandir"), ${ }^{34}$ ou seja, a

\footnotetext{
${ }^{34}$ Art. $3^{\text {o }}$. O imposto não incide sobre:[...]II - operações e prestações que destinem ao exterior mercadorias, inclusive produtos primários e produtos industrializados semielaborados, ou serviços.
} 
exclusão do campo de incidência do ICMS da exportação dos produtos primários e dos semielaborados, sem honrar os deveres de compensação pela perda de arrecadação. ${ }^{35}$

Acresce ainda que a União alargou a incidência dos tributos sobre o consumo, dentro da sua esfera de competência, minando a base econômica do ICMS dos Estados. Ao criar as contribuições sociais não cumulativas, que a rigor quase dobraram a arrecadação federal antes existente, instituiu um verdadeiro ICMS federal (PIS e COFINS). Preferiu utilizar as contribuições sociais exatamente para não compartilhar o produto arrecadado com Estados e Municípios. Então, se por um lado a União não compensou os Estados pelas desonerações das exportações, reduzindo-lhes a arrecadação, por outro, ainda avançou sobre os impostos sobre o consumo, por meio das contribuições PIS/COFINS, corroendo a base econômica - a mesma do ICMS - que se esgota em mãos federais.

Acresce ainda que a União, ao longo dos anos, aprovou renúncias a impostos cuja arrecadação deveria ser compartilhada com os Estados (exonerações do IPI, como em 2009; exonerações do IR, como lucros e dividendos distribuídos) e, para cobrir seu déficit, ampliou as contribuições sociais (tributos não compartilhados), desvinculando parcela das receitas. Com isso, os recursos foram se concentrando no Ente federal, em claro movimento centrípeto, contrário à tendência centrífuga idealizada pelo constituinte de 1988.

Como se não bastasse, a União vem usurpando a competência dos Estados para tributar heranças e doações. Sendo acréscimo ao patrimônio do beneficiado, poderiam tais fatos (as doações e as transmissões causa mortis) configurar, ao mesmo tempo, hipóteses tributáveis por meio do imposto de renda (ganho de capital), sendo contribuintes o herdeiro ou o donatário? A Constituição Federal responde que não. Seguindo o modelo de sistema tributário mais usual, tal como ocorre na Europa e Américas, ela autonomizou essas formas de aquisição (por causa de morte e por meio de doação), para isso criando espécie independente que entregou à competência tributária dos Estados membros. O Supremo Tribunal Federal sempre rechaçou, no passado, as tentativas da União de tributar o ganho de capital, decorrente de herança ou doação. Em todos esses

\footnotetext{
${ }^{35}$ Art. 31. Até o exercício financeiro de 2.002, inclusive, a União entregará mensalmente recursos aos Estados e seus Municípios, obedecidos os limites, os critérios, os prazos e as demais condições fixados no Anexo desta Lei Complementar, com base no produto da arrecadação estadual efetivamente realizada do imposto sobre operações relativas à circulação de mercadorias e sobre prestações de serviços de transporte interestadual e intermunicipal e de comunicação no período julho de 1995 a junho de 1996, inclusive.
} 


\section{FEDERALISMO, LIBERDADE E DIREITOS FUNDAMENTAIS}

casos, entendeu a Corte que o imposto sobre a renda (lucro imobiliário) não atinge bens havidos causa mortis. (STF. RE 36163, $1^{3}$ T., DJ 21-03-60, p. 00702; RE 36777-DF, $2^{\mathrm{a}}$ T., DJ 03-09-59, Ement., vol. 00399-02, p. 00483; ERE 0036777-GB, Tribunal Pleno, DJ 07-10-60, p. 05957; RE 36973, Tribunal Pleno, DJ 15-05061, p. 00054.)

Efetivamente, nenhum dos países, que adotam modelo tributário como o nosso, admite submeter simultaneamente tais transmissões causa mortis e doações ao imposto de renda. A rigor, nesses sistemas, o imposto sobre a transmissão por causa de morte e doação é complementar ao imposto de renda. Daí a pessoalidade e a progressividade conferidas a ambos. Vale dizer, a renda ou os lucros devem ser gerados pelo capital e trabalho advindos do próprio patrimônio do contribuinte. Ao contrário, somente naqueles países em que o imposto de heranças e doações inexiste como espécie independente, é que o imposto de renda alcança objetividade. Em tal hipótese, heranças e doações são confundidos com os ganhos de capital do herdeiro ou donatário, havendo então acréscimos produzidos externamente por outro patrimônio. Seria o caso do Canadá. Aliás, os demais países, no resto do planeta, que adotam o mesmo modelo do Brasil, com impostos sobre heranças e doações independentes, impõem exações muito expressivas, não experimentadas entre nós. Sobre o valor de mercado dos bens transferidos, a progressividade é elevada. Considerando-se as faixas de valor mais alto, os EEUU impõem alíquotas de até $50 \%$, somados o tributo federal e o estadual; a Inglaterra de $40 \%$; a Alemanha de $35 \%$ a 50\%, conforme o grau de parentesco; a França de $40 \%$; a Itália de $27 \%$ ou $33 \%$, etc. 36 Não somente supõem esses ordenamentos que o Estado, por meio do imposto incidente sobre as heranças e doações, apropria-se integralmente dos ganhos de capital (pois a base imponível é o valor do bem), como ainda rejeitam uma nova incidência por meio do imposto de renda, por seus efeitos confiscatórios.

Não obstante, essa questão, em verdade, não está em discussão, pois a subutilização pelos Estados membros das bases potenciais do imposto sobre heranças e doações não pode ter o condão de deslocar a competência tributária para a União. Em especial, às custas da violação do conceito de renda, da perda dos limites formais do jurídico. É evidente que, se os Estados Federados quiserem exercer plenamente a competência a que fazem jus (desde que se modifiquem as resoluções do Senado

${ }^{36}$ Cf. PLÜCKEBAUM et al. Einkommensteuer. Erich Fleisher Verlag. Achim, 1991; e Code Général des Impôts. Paris: Dalloz, 1996. Ver atualização de tais dados em BALLEIRO, Aliomar. Direito tributário brasileiro. Atualiz. por Misabel Abreu Machado Derzi. Rio de Janeiro: Forense, 2010, p. 1167-1181. 
Federal), não mais encontrarão sua base tributária plena, em razão da "invasão" praticada pela União.

A Lei federal $n^{\text {o. }}$.9532/97 supõe, erroneamente, que o titular de um bem, à medida que o preço de mercado se eleva acima do custo de aquisição declarado, aufere ganhos de capital que, finalmente, se realizam com a sua morte. Ora a morte não pode ser a realização do ganho, porque ela desapossa o de cujus não somente da vida como de todo o seu patrimônio, seja móvel ou imóvel. Segundo a lei, determina-se, então, a incidência do imposto sobre o ganho "auferido" pelo morto e transmitido aos herdeiros, como espécie de dívida (embora o recolhimento do imposto sobre a renda devido possa ser diferido pelo herdeiro para momento posterior quando houver nova transmissão, como se fora um favor). E, mesmo em caso de diferimento, o custo de aquisição declarado pelo de cujus continuará sendo sempre o parâmetro, prendendo-se, em cadeia, as declarações futuras de sucessores e donatários. Em transmissão posterior, o herdeiro e atual proprietário dos bens deverá pagar o ganho de capital auferido pelo de cujus.

Portanto, antes interessa saber se a morte ou outro sinistro qualquer configura realização para o de cujus do ganho de capital. Ora, a morte é o mais grave dos sinistros; é perda que não desencadeia ganho de capital ou acréscimo para o de cujus (de modo que nenhum ganho de capital há para ser herdado). A Lei $\mathrm{n}^{\circ}$. 9532/97 pressupõe que os sucessores se beneficiam de um favor legal, qual seja a possibilidade de diferimento para a transmissão posterior, como se tivessem incorporado o ganho (ou mais valia) meramente potencial do de cujus, que se realiza com a morte. E isso é inaceitável.

É fácil concluir que, por meio do IR, a União apoderou-se do imposto estadual sobre heranças e doações, minando a sua base. A alíquota máxima do IR sobre ganhos de capital alcança $22,5 \%$ do valor do ganho, enquanto o imposto sobre heranças e doações está limitado à alíquota de $8 \%$ por força de resolução do Senado Federal. Dificilmente os Estados conseguirão aumentar o imposto de sua competência, pelo menos substancialmente, porque a União já lhe esgotou a base econômica potencial.

(d) inexistência de normas e critérios para a concessão de transferências voluntárias, de modo que a União pode usar politicamente seus recursos em favor de um e detrimento de outros Estados, com grave ofensa à igualdade e paridade de tratamento; acresce ainda que recursos financeiros não podem ser canalizados para Estados que já receberam acima de certa média, ou que têm receita muito elevada, considerando a média nacional. Nem tampouco tais recursos podem ser utilizados para direcionar a política estadual, como já alertamos. 
Enfim, esse apenas um brevíssimo resumo, sem pretensão de completude, de alguns problemas mais recentes de violações ao federalismo brasileiro.

Só quem não soube a sombra, não reconhece a luz.

\section{CONClusÃo}

O Somente a implementação da Constituição da República poderá devolver a autonomia de cada um dos Estados membros e de seus Municípios. E a garantia dessa autonomia é, singelamente, a preservação da democracia. Na verdade é nada mais do que o respeito à liberdade daquele povo do território daquele Ente estadual. E, por detrás de um Estado, há direitos individuais e sociais fundamentais a serem protegidos.

É fundamental que o nosso Senado Federal passe a trabalhar em favor dos Estados que representa. Ou se dá uma transformação comportamental e funcional de seus membros, ou deveríamos substituir a estrutura atual de nosso Congresso Nacional, para introduzir um Conselho Federal à moda alemã, voltado à construção de um federalismo de política conjunta.

Ocorre ainda que não há como garantir a efetividade dos direitos fundamentais, se a União pode fazer bloqueios inconsequentes nas contas dos Estados, expropria-los sumariamente como aconteceu recentemente com o Estado do Rio de Janeiro. Os cidadãos desse Estado têm direitos individuais fundamentais a proteger. Eles têm direito à segurança pública, à vida, à saúde, à educação e de qualidade.

E como diriam os alemães, a quem podemos acompanhar, os cidadãos do Estado do Rio de Janeiro têm direitos iguais a um padrão de vida média semelhante, ao dos demais Estados, mesmo de São Paulo, à saúde, educação, segurança. Razão pela qual sempre considerei inconstitucionais as sanções institucionais, impostas pela Lei de Responsabilidade Fiscal. Quando algum Ente político se desalinha das metas e limites nela fixados, ela proíbe a transferência de recursos federais para aquele Estado. Configura mesmo crime praticado pelo administrador estadual receber tais recursos. Tal sanção é política e institucional e pune os cidadãos daquele Estado faltoso, o que é inaceitável. Que se anulassem os atos ilícitos e se punisse pessoalmente o administrador responsável, mas jamais os cidadãos daquele Estado.

Segundo a Constituição da República, os Estados Federados ou os Municípios não precisam manter uma comunidade virtuosa para merecer a proteção constitucional. A Constituição trata igualmente a todos os Estados e Municípios como se virtuosos fossem porque o que se protege 
por detrás de qualquer Ente Estatal não é o aparato administrativo em si, nem a qualidade da gestão, mas a soberania que advém do povo, dos cidadãos que o legitimam. O direito de cada um de nós a uma liberdade decisória, o direito de cada um de nós a uma vida produtiva e ao pleno desenvolvimento de nossas potencialidades. E esse tratamento tem consequências felizes, importantes. Uma dessas consequências é exatamente limitar e controlar o poder federal.

Um Federalismo para a liberdade. É isso que a Constituição determina, para afastar os riscos do retorno de uma ditadura. Para isso é necessário que o Federalismo brasileiro caminhe para um Federalismo de política conjunta, harmonioso, amistoso e leal, em que um Senado atento e participativo proteja os interesses estaduais, não tolerando a imposição de política federal, unilateral e contrária aos interesses dos Estados e Municípios. Ao mesmo tempo, um Federalismo mais igualitário é imposto pela Constituição em seus objetivos e metas. Nenhum cidadão poderá ser privado de seus direitos fundamentais à vida, à segurança pública, à saúde e à educação por meio dos bloqueios dos recursos estaduais pela União. O Federalismo tem como meta garantir exatamente a efetividade desses direitos fundamentais.

Imoral, imoral é violar a Constituição. Imoral é enfraquecer a democracia brasileira, centralizando, fragilizando a Federação e coibindo importante instrumento de dispersão do poder no território nacional. Não basta para nós, brasileiros, apenas a diluição do poder no sentido horizontal, por meio da separação de poderes. O Supremo Tribunal Federal precisa, como guardião da Constituição, no enfrentamento contra o abuso de poder dos demais poderes, ser auxiliado por um Federalismo que, de fato e de direito, propicie a difusão do poder pelo território nacional.

Quem não soube da sombra, não reconhece a luz.

\section{REFERÊNCIAS}

AGUIAR, Joaquim de Castro de. Competência e Autonomia dos

Municípios na nova Constituição. Rio de Janeiro, Forense, 1993.

BALLEIRO, Aliomar. Direito tributário brasileiro. Atualiz. por Misabel Abreu Machado Derzi. Rio de Janeiro: Forense, 2010.

Limitações Constitucionais ao Poder de Tributar. Atualiz.

DERZI, Misabel. 8ª . ed. Rio de Janeiro, 2010. 
BARACHO, José A. O., Teoria Geral do Federalismo. UCMG, 1982.

BARBOSA, Rui. Obras Completas, vol. VUU, t.1. A Constituição de 1891. Rio de Janeiro, 1946.

BARROSO, Luís Roberto. O novo direito constitucional brasileiro: contribuções para construção teórica e prática da jurisdição constitucional no Brasil. Editora Fórum, 2012.

. Direito Constitucional Brasileiro: o problema da Federação.

Rio de Janeiro: Forense, 1982.

BATISTA JÚNIOR, Onofre Alves. O projeto democráticodescentralizador da Constituição e o acerto de contas. Revista Consultor Jurídico. Disponível em: <http://www.conjur.com.br/2017jun-27/onofre-junior-projeto-democratico-descentralizadorconstituicao >. Acesso em: 28 jun. 2017.

BOTHE, Michael. Federalismo, um conceito em transformação histórica. In: SCHULTZE, Rainer-Olaf O. Federalismo na Alemanha. Fundação Konrad Adenauer-Stiftung: Traduções, n. 7, 1995.

DAHL, Robert A. Decision-Making in a Democracy: The Supreme Court as a National Policy-Maker. Journal of Public Law. n. 6, 1997.

DORF, Michael C. Instrumental and Non-Instrumental Federalism. Rutgers LJ, v. 28, p. 825, 1996.

FERRARI, Sérgio. Constituição Estadual e Federação. Rio de Janeiro: Lumen Iuris, 2003.

FISCHER, Frank. Democracy and Expertise: reorienting public inquiry. Oxford University Press. 2009.

FIGUEIREDO. L. Valle. Curso de Direito Administrativo. 2 ed. São Paulo: Malheiros Editores, 1995. 
FOUCAULT, Michel. A verdade e as Formas Jurídicas. Trad. Roberto Cabral de M. Machado e outro. $4^{\mathrm{a}}$. Rio de Janeiro. Cadernos da PUC/RJ n. 16, 1979;

HAMILTON, Alexander; MADISON, James. JAY, John. MADISON, James. O Federalista, XLVII. Rio de Janeiro: Nacional de Direito, 1959.

HESSE, Joachin Jens. República Federal da Alemanha: do federalismo cooperativo à elaboração de política conjunta. In: SCHULTZE, RainerOlaf O. Federalismo na Alemanha. Fundação Konrad AdenauerStiftung: Traduções, n. 7, 1995.

HORTA, Raul Machado. Estudos de Direito Constitucional, Belo Horizonte: Del Rey, 1995.

KELSEN, Hans. Teoria General del Derecho y del Estado. Trad.

Eduardo Garcia Maynez, 2a. ed. México: Imprenta Universitária, 1958.

MADISON, James; HAMILTON, Alexander; JAY, John. Os Artigos federalistas 1787-1788: edição integral. Nova Fronteira, 1993.

MAGALHÃES, Tarcísio Diniz. Governança Tributária Global: limitações externas ao poder de tributar e de não tributar na pósmodernidade. Belo Horizonte: Arraes, 2016.

MIRANDA, Pontes de. Comentários à Constituição de 1967. São Paulo: Revista dos Tribunais, v. 4, 1967.

MURPHY, Walter F. et al. American constitutional interpretation. Foundation Press, 1986.

PRADO, Sérgio Prado. Equalização e Federalismo Fiscal- Uma análise comparada: Alemanha, Índia, Canadá, Austrália, Brasil. Fundação Konrad Adenauer. Rio de Janeiro, 2006. 
RICHTER, Ingo; SCHUPPERT, Gunnar Folke. Casebook Verfassungsrecht. CH Beck, 1987.

SCHULTZE, Rainer-Olaf O. Federalismo na Alemanha. Fundação Konrad Adenauer-Stiftung: Traduções, n. 7, 1995.

SOUZA, Jessé. A tolice da Inteligência Humana: ou como o País se deixa manipular pela elite. São Paulo: Leya, 2015.

STIGLITZ, Joseph E. The Euro: how a common currency threatens the future of Europe. Nova York: Northon y Company, 2016.

SILVA, José Afonso da. Curso de Direito Constitucional Positivo. 9ª ed. São Paulo: Malheiros, 1994.

FEDERALISMO, LIBERDADE E DIREITOS FUNDAMENTAIS

FEDERALISM, FREEDOM AND FUNDAMENTAL RIGHTS 